\title{
MIEJSCA ODBYWANIA SEJMIKÓW KORONNYCH NA WYGNANIU W LATACH 1648-1696
}

\author{
Jarosław Stolicki \\ Uniwersytet Jagielloński w Krakowie
}

\section{ABSTRACT \\ THE SEATS OF CROWN DIETINES IN EXILE, 1648-1696}

As a result of the wars of the second half of the $17^{\text {th }}$ century, the gentry from a number of provinces of the Polish-Lithuanian Commonwealth were forced to seek refuge from the enemy in other, safer provinces, and to hold their dietines in exile. In the years 1648-1649, the gentry from a number of Lesser Poland provinces were temporarily displaced, but most of them soon returned to their abodes. Citizens of the Ukrainian provinces were less fortunate. The Czerhnigovian, Bratslavian and Kievan gentry held virtually all of their dietines in that period in Włodzimierz in Volhynia. They convened in the Uniate cathedral church and in the Dominican Friars' church. In their resolutions they continuously underscored the provisional but legal character of the place of their deliberations. The Ukrainian exiles (except Czernigovians) returned to their abodes in the $18^{\text {th }}$ century. From 1672 to 1698 , the Podolian gentry held their dietines in Halicz and later in Lviv (in Franciscan churches), and in 1699 in the Trinity Trenches, while Kamieniec Podolski was under Ottoman control.

Key words: Ukrainian dietines, Włodzimierz, exiles, churches.

Słowa kluczowe: sejmiki ukrainne, Włodzimierz, wygnanie, kościoły.

Od roku 1648 niektóre sejmiki odbywały się w innych miejscach niż zwyczajowe, co było skutkiem prowadzonych działań wojennych. W niniejszym artykule przedstawiono problemy dotyczące miejsc odbywania zgromadzeń w prowincji małopolskiej: bracławskiego, kijowskiego i czernihowskiego oraz podolskiego, a sporadycznie także ruskiego i wołyńskiego.

Przed rokiem 1648 szlachta z województwa kijowskiego odbywała zgromadzenia najpierw w Kijowie, a od czasów Stefana Batorego w Żytomierzu. Sejmiki województwa bracławskiego zbierały się w Bracławiu, a po jego zniszczeniu (od 1598 r.) 
w Winnicy ${ }^{1}$. Szlachta województwa czernihowskiego obradowała w jego stolicy². Podolanie zaś gromadzili się w Kamieńcu.

Do zmian doszło w czasie powstania Chmielnickiego. Sejmiki przed konwokacją po śmierci Władysława IV zostały zwołane na 25 czerwca. W tym czasie duża część ziem wschodnich była ogarnięta powstaniem. Klęski spowodowały rozkład aparatu państwowego na Ukrainie, a szlachta uciekała w panice. Wiemy jedynie, że Kijowianie zgromadzili się w Żytomierzu³. Nie dysponujemy żadnymi informacjami o tym, gdzie odbyły się inne zjazdy ukrainne. Ich miejsca obrad znajdowały się na terenach objętych powstaniem lub $\mathrm{w}$ jego pobliżu. W uchwałach sejmu wyznaczono jedynie terminy zgromadzeń pokonwokacyjnych, a ich miejsc nie podano ${ }^{4}$. Nie mamy o nich informacji, podobnie jak o sejmikach deputackich.

Kolejne zmiany miejsca odbywania zjazdów nastąpiły pod koniec 1648 roku. Sejm elekcyjny wyznaczył sejmiki relacyjne: „Woiewodztwu Kiiowskiemu, Ruskiemu, Wołyńskiemu, Podolskiemu, Bracławskiemu, Czerniechowskiemu... ponieważ na mieyscach zwykłych Seymikow mieć nie mogą... tu w Kościołach Warszawskich 23 Novembris"s. Dnia 17 listopada dokonano wyboru władcy, a 23 listopada marszałek poselski pożegnał posłów i na ten dzień właśnie wyznaczono te zgromadzenia. Miała w nich więc wziąć udział ta część szlachty, która uczestniczyła w elekcji. Były to zarazem zjazdy przed koronacją.

Zamieszanie towarzyszyło sejmikowi generalnemu ruskiemu. Odbyły się dwa sejmiki, z których żaden nie obradował na miejscu zwyczajowym, czyli w Wiszni. Część szlachty zebrała się właśnie w Warszawie, a druga grupa w Przemyślu 15 grudnia $^{6}$. Ten ostatni został zwołany przez kasztelana przemyskiego Felicjana Grochowskiego. W laudum i instrukcji zebrani pokrótce wyjaśnili, że obrady odbywają się w Przemyślu z powodu zagrożenia ich ziem najazdem nieprzyjaciela. Protestowali

1 K. Mazur, W stronę integracji z Korona. Sejmiki Wolynia i Ukrainy w latach 1569-1648, Warszawa 2006, s. 37-39, 41, 48-49, 54, 57-58, 61, 69-70.

2 W konstytucji sejmu z 1633 r.: Ordynacya Czerniechowska [w:] Volumina Legum [dalej: VL], t. III, s. 381-382, ustalono, że w Czernihowie będzie wybieranych dwóch posłów, a na mocy tej z 1635 r.: Ordynacya Woiewodztwa Czernichowskiego, VL, t. III, s. 410-411, postanowiono utworzyć województwo czernihowskie z dwoma powiatami - czernihowskim i nowogrodzkim.

3 Uniwersal Macieja Lubieńskiego, VL, t. IV, s. 72-74; Latopisiec albo kroniczka Joachima Jerlicza, t. I, z rękopisu wydał K.W. Wóycicki, Warszawa 1853, s. 66, 69. Do Żytomierza przybył ze swoim wojskiem i szlachtą z lewego brzegu Dniepru Jeremi Wiśniowiecki i dzięki temu na tym terenie nie było wówczas powstania chłopskiego.

${ }_{4}$ Konfederacya generalna, VL, t. IV, s. 83, 84. Terminy sejmików nas interesujących wyznaczono przeważnie na dzień elekcji deputackiej.

5 Deklaracye woiewodztw y ziem koronnych, ratione obrony, VL, t. IV, s. 92. O zakończeniu elekcji pisałem wcześniej: J. Stolicki, Prolongowanie sejmów w drugiej połowie XVII wieku, „Czasopismo Prawno-Historyczne" 1997, t. XLIX, z. 1-2, s. 249, 250. Oznaymienie króla nowo-obranego..., VL, t. IV, s. 91.

6 Dokumenty zostały wydane w: Akta grodzkie i ziemskie z czasów Rzeczypospolitej Polskiej $z$ archiwum tzw. bernardyńskiego we Lwowie, t. XXI: Lauda sejmikowe, (t. II: Lauda wiszeńskie 1648 1673), oprac. A. Prochaska, Lwów 1911 [dalej: AGZ], s. 41-53. O rozwiązaniu problemu podwójnego kompletu posłów ruskich podczas sejmu pisała S. Ochmann, Sejm koronacyjny Jana Kazimierza w 1649 r., Wrocław 1953, s. 87-91. 
także przeciwko odbywaniu prywatnych konsultacji w „nienależytej ziemi”, czyli przeciwko zgromadzeniu w Warszawie ${ }^{7}$.

Sejm koronacyjny postanowił, że sejmik relacyjny i deputacki kijowski odbędzie się w Łucku w klasztorze Dominikanów, a bracławski we Lwowie w kościele Franciszkanów. Stany zaaprobowały deputatów czernihowskich, którzy zostali wybrani w Warszawie, a miejsce sejmiku relacyjnego wyznaczono u Dominikanów w Lublinie. Sejmik generalny ruski miał obradować w Wiszni, a bełski, chełmski, wołyński i podolski też raczej miały się odbyć w zwyczajowych miejscach ${ }^{8}$.

Szlachta województwa kijowskiego i wołyńskiego na sejmiku relacyjnym zebrała się w Łucku 15 marca 1649 roku $^{9}$, a obywatele czernihowscy w Lublinie ${ }^{10}$.

Wznowione w 1649 roku walki z Kozakami zakończyły się zawarciem 19 sierpnia ugody zborowskiej. Po niej Jan Kazimierz wydał uniwersały do szlachty województw ukrainnych i naznaczył im Włodzimierz jako miejsce elekcji deputackich ${ }^{11}$. Monarcha, zwracając się do szlachty bracławskiej, przypomniał: „przypada według prawa elekcyja deputacka... w Winnicy”. Nie mogą jednak zjechać tam, ,ponieważ tak prędko wojsko nasze zaporoskie powagą naszą uspokojone, od zbuntowanego pospólstwa oddzielone bydź nie może... Ponieważ pod ten czas niemal wszyscy z Uprzejmości i Wierności Waszych w województwie wołyńskim przemieszkiwają zjazdu takowego na czas wyżej wspomniany miejsce we Włodzimierzu tym uniwersałem naszym naznaczamy"'2. Deputaci mieli być traktowani tak, jakby zostali obrani w Winnicy. Analogiczne uniwersały wysłano do szlachty kijowskiej i czernihowskiej.

Zgodnie z tymi uniwersałami szlachta ukrainna zebrała się we Włodzimierzu. Warto zwrócić uwagę, że obywatele trzech województw obradowali wspólnie, co będzie niekiedy praktykowane podczas odbywania zgromadzeń na wygnaniu ${ }^{13}$.

7 AGZ, t. XXI, s. 52.

8 Deklaracye Woiewodztw, VL, t. IV, s. 124-125. Jedynie w przypadku kijowskiego zaznaczono, że nie może się odbyć w Kijowie. Aprobowano też deputatów województwa wołyńskiego obranych w Krzemieńcu.

9 Laudum sejmiku relacyjnego województwa kijowskiego, Łuck 15 III 1649, Архив Юго-западной России, издаваемый временной комиссией для разбора древних актов, состоящей при Киевском, Подольском и Волынском генерал-губернаторе, Ч. 2: Т. I, Киев 1861, s. 349-369 [dalej: AJZR, cz. 2, t. I].

10 Laudum sejmiku relacyjnego województwa czernihowskiego, Archiwum Państwowe w Lublinie, księgi grodzkie lubelskie, RMO, ks. 77, k. 223v-229. Laudum sejmiku deputackiego województwa czernihowskiego, Archiwum Państwowe w Lublinie, księgi grodzkie lubelskie, RMO, ks. 77, k. 709-709v; Biblioteka PAU i PAN w Krakowie, rkps 8355, k. 30-30v (jest to odpis z tej samej księgi). W uchwałach uzasadniono, że nie mogą obradować w zwyczajowym miejscu z powodu swawoli kozackiej.

11 Uniwersał Jana Kazimierza do województwa kijowskiego naznaczający elekcję deputacką we Włodzimierzu, w obozie pod Gliniany 25 VIII 1649, Centralnyj Dierżawnyj Istorycznyj Archiw Ukrainy u Kijewi [dalej: CDIAUK], f. 28, ks. 85, k. 431-432v; Uniwersał do województwa bracławskiego, CDIAUK, f. 28 , ks. 85 , k. 432v-444; Uniwersał do województwa czernihowskiego, CDIAUK, f. 28, ks. 85 , k. 444-445v. Pisownię w starych wydawnictwach pozostawiono bez zmian, a w źródłach rękopiśmiennych zastosowano się do zasad instrukcji wydawniczej.

12 Ibidem, k. 443.

13 Atestacja sejmiku deputackiego województw: kijowskiego, bracławskiego i czernihowskiego we Włodzimierzu. 13 września 1649 , CDIAUK, f. 28, ks. 85, k. 448-449v. O wspólnym odbywaniu zgromadzeń ukrainnych pisałem niedawno: J. Stolicki, Sejmiki ukrainne w latach 1648-1702. Problemy 
W atestacji danej deputatom zapisano, że zebrali się w cerkwi katedralnej włodzimierskiej, ,gdzie elekcyje zwykły odprawować się województwa wołyńskiego... ponieważ województwa nasze i miejsca, na których zwykliśmy ordinarie odprawować sejmiki jeszcze od nieprzyjaciela wolne nie są, a JKM p.n.m. naznaczyć nam raczył zjazd generalny na elekcyją deputacką uniwersałami swymi... tu we Włodzimierzu"14. Mocno więc podkreślono legalność miejsca obrad.

Najbliższe sejmiki przedsejmowe odbyły się w październiku 1649 roku. Nie zachował się uniwersał królewski do żadnego województwa, więc nie wiemy, jakie miejsca wyznaczono obywatelom. $\mathrm{Z}$ podjętych uchwał znamy jedynie instrukcję szlachty bracławskiej ${ }^{15}$. Na temat sejmiku kijowskiego z 11 października zachowały się krótkie informacje. Wojewoda kijowski Adam Kisiel pisał do Bohdana Chmielnickiego, że z powodu działań czerni obywatele musieli „Sejmik odprawić pod niebem nad rzeką Słuczą, tem samem kontentując się, że na kijowskiej ziemi, choć nie na miejscu zwykłem"'16. Jerlicz dodaje, że odbył się we wsi Zatki, pół mili od Zwiahela. Nie wiadomo, gdzie debatowali Czernihowianie.

W deklaracjach województw znajdujemy ważne postanowienia. Bracławianie „Seymik pro die ultima Iannarij [sic] we Włodzimierzu, tamże jeśliby ad possessionem dobr swoich nie przyszli, y drugie Seymiki y Elekcye odprawować mają"17. Wyznaczono więc nowe miejsce obrad, także na przyszłość. Równie istotne postanowienie dotyczyło sejmiku czernihowskiego, który ,pro hac una vice w Żytomierzu, in simul et semel z Woiewodztwem Kiiowskim ultima Februarij" ${ }^{18}$. Zapisano też, że Kijowianie mają się zebrać 21 lutego 1650 roku. Wynika z tego, że zgromadzenie szlachty kijowskiej wróciło na swe zwyczajne miejsce, a jako egzulanckie pozostały zjazdy bracławskie i czernihowskie.

Ziemianie kijowscy i czernihowscy zjechali na wspólny sejmik w Żytomierzu 7 marca 1650 roku $^{19}$ i tam odbywali kolejne zgromadzenia przez dwa lata. W instrukcjach tych sejmików na sejm z 15 grudnia 1651 roku znajdujemy informacje dotyczące obradowania w Żytomierzu. Obywatele czernihowscy liczyli na powrót do

badawcze [w:] PATRIMONIUM Студії з ранньомодерної історії Центрально-Східної Свропи, Том 1: Ранньомодерна людина: простір - влада - право XVI-XVIII ct., Київ-Краків 2015, s. 235-236.

14 CDIAUK, f. 28, ks. 85, k. 449. Dalej zaś podkreślono, że to na Wołyniu znaleźli swoje receptaculum.

15 Instrukcja sejmiku województwa bracławskiego posłom na sejm dana, we Włodzimierzu $11 \mathrm{X}$ 1649, CDIAUK, f. 28, ks. 85, k. 476-480v. W instrukcji zapisano: „w cerkwi katedralnej unickiej, na miejscu sejmikom zwykłym, odprawionego".

${ }_{16}$ Odpis wojewody kijowskiego na tenże, dan między Zwiahlem a Niesolonna dnia 20. 8bris r. 1649 [w:] Ojczyste spominki w pismach do dziejów dawnej Polski..., t. II, z rękopisów zebrał A. Grabow ski, Kraków 1845, s. 123-127; Latopisiec..., s. 109-110. W sejmiku tym wzięła udział szlachta, która wcześniej uciekła z Ukrainy i przyjechała z Kisielem, a w Żytomierzu czekało kilkanaście osób. Księgę grodu żytomierskiego zaczęto prowadzić 5 XII 1649: „po uspokojeniu swawolnej rebelyjej kozackijej i chłopskijej, zaczynamy akta grodu tutejszego", CDIAUK, f. 11, ks. 13, k. 1.

${ }_{17}$ Deklaracye Woiewodztw y Ziem Koronnych podatkow, tak na zapłatę dtugow Rzepltey, iako też na żołd extraordynaryinemu woysku uchwalonych, VL, t. IV, s. 144.

18 Ibidem, s. 144, 143.

19 Laudum na sejmiku żytomirskim uchwalone przez ichm. panów obywatelów województwa kijowskiego i czernihowskiego, CDIAUK, f. 11, ks. 13, k. 82-84. 
swych posiadłości. Okazało się jednak, że konflikty z Kozakami nie zostały zakończone, w związku z czym „nie mogło tedy mieć woiewodstwo nasze ani powracania do domów własnych, ani w Czernihowie sejmikowania securitatem"20. Sporo miejsca w instrukcji zajmują kwestie dotyczące przywrócenia porządku. Czernihowianie żądali też przyznania im reclinatorium jako egzulantom. Zalecali posłom współdziałanie z posłami kijowskimi i wzajemne popieranie swych postulatów.

W księgach włodzimierskich z lat 1650-1651 nie znaleziono żadnych dokumentów dotyczących sejmików bracławskich. Sejm grudniowy z 1650 roku wyznaczył Bracławianom sejmik na 16 stycznia, a ,ieżliby dla niebeśpieczeństwa ziachać nie mogli, tedy we Włodzimierzu w tydzień potym Seymik ten sobie naznaczaią" ${ }^{21}$.

W księdze włodzimierskiej z roku 1652 nie zachowały się żadne dokumenty dotyczące województw ukrainnych. Nie wiemy, gdzie odbyły się sejmiki, zwłaszcza że po klęsce pod Batohem nastąpiło znaczne osłabienie wpływów polskich na Ukrainie. Sejmik przedsejmowy wołyński zebrał się zaś we Włodzimierzu, co nie było zgodne ze zwyczajem ${ }^{22}$. Powodem przeniesienia go było nie tylko morowe powietrze, ale także zagrożenie działaniami nieprzyjaciela.

Konstytucja sejmu z 1652 roku wyznaczyła, że sejmiki ukrainne relacyjne odbędą się „na elekcyi Deputackiey”. Bracławianie mieli się zebrać we Włodzimierzu, a w przypadku epidemii - w polu pod Zimnym (tam także planowali się zgromadzić Wołynianie). Miejsce debatowania szlachty kijowskiej miał z kolei wskazać tamtejszy senator, a czernihowska „także iako y Kiiowskie odprawować będzie”23.

Nieco więcej informacji na temat okoliczności odbywania sejmików województw ukrainnych przynoszą kolejne wydarzenia. Przed sejmem w Brześciu wojewoda kijowski Adam Kisiel wydał uniwersał do ziemian swego województwa. Przypomniał o wyznaczeniu przez monarchę terminów sejmików i sejmu. Następnie zauważał:

[...] gdy tedy nam afflictis exulibus ukrainnym non datur facultas na miejscu zwykłym w Żytomirzu pod bokiem nieprzyjacielskim gromadzić się i konsultacyje nasze odprawować, za wolą JKMci we Włodzimierzu (gdzie i wojewódstwo brasławskie i czernihowskie obrali sobie) miejsce sejmiku w katedralnej włodzimirskiej cerkwie (gdzie zwykły wołyńskiego wojewodstwa odprawować się zjazdy i elekcyje) naznaczam ${ }^{24}$.

Województwa ukrainne zebrały się na sejmiku przedsejmowym we Włodzimierzu i uchwaliły jedną instrukcję, w której czytamy: „obywatelów... woiewódstw, od nieprzyjaciela in exilio będących, do miasta Włodzimirza (ponieważ pomienione

20 Instrukcja szlachty województwa czernihowskiego posłom na sejm, Żytomierz 15 XII 1651, AJZR, cz. 2, t. I, s. 426-433. W instrukcji napisano: „w Żytomirzu, spólnie z woiewodstwem Kiiowskim, według prawa y constitucyey".

21 Deklaracya Woiewodztw, VL, t. IV, s. 157.

22 Instrukcja sejmiku województwa wołyńskiego posłom na sejm, Włodzimierz 11 VI 1652, AJZR, cz. 2, t. I, s. 434-439.

23 Deklaracye Woiewodztw y Ziem, VL, t. IV, s. 178-181.

24 Oblata uniwersału wojewody kijowskiego Adama Kisiela do szlachty województwa, w Gnojnie 24 II 1653, CDIAUK, f. 28, ks. 89, k. 562v-563v (cyt. fragment k. 563-563v). Warto zwrócić uwagę na fragment, w którym mowa o tym, że w cerkwi odbywają się już zgromadzenia województwa wołyńskiego. Nie są znane natomiast uniwersały monarchy. 
wojewodstwa in hostico zostają)"25. Jak niedawno zwróciłem uwagę, pojawiła się nowa praktyka wyznaczania miejsca obrad, stosowana w latach 1653-1654. Monarcha podawał jedynie datę sejmiku, a miejsce wyznaczał senator województwa ${ }^{26}$.

Od tej pory do 1661 roku województwa ukrainne zbierały się we Włodzimierzu. Tę miejscowość wyznaczyła konstytucja sejmu brzeskiego ${ }^{27}$, tam odbyły się jedyny znany sejmik relacyjny (bracławski) ${ }^{28}$ oraz deputackie. Zmiana dotyczyła konkretnego miejsca zgromadzenia ziemian kijowskich i czernihowskich, którzy obradowali w kościele Dominikanów. Szlachta bracławska (Wołynianie również) zebrała się natomiast w cerkwi katedralnej unickiej ${ }^{29}$.

W każdym z tych dokumentów uzasadniono odbywanie sejmików we Włodzimierzu, na przykład Czernihowianie napisali: „ponieważ do Czernihowa dla rebelijej i buntów chłopskich, a wojny z Kozakami i dotąd zjachać trudno było"30.

Przed kolejnym sejmem ponownie trzy województwa ukrainne zebrały się na sejmiku przedsejmowym we Włodzimierzu i uchwaliły jedną instrukcję $e^{31}$. O miejscu zawiadomił obywateli wojewoda kijowski ${ }^{32}$. Nie uzasadniono tego nawet $w$ uchwałach. Wojna z Kozakami nie przynosiła sukcesów i powoli zaczynano rozumieć, że bez zwycięstwa lub innego korzystnego rozwiązania nie nastąpi powrót do swych dóbr.

W kwietniu 1654 roku monarcha wydał uniwersały, w których zwołał kolejny sejm i wyznaczył terminy sejmików przedsejmowych. Zachowały się te wysłane do województw bracławskiego i czernihowskiego. Znajdujemy tam następujące informacje: ,składamy... sejmik powiatowy tam gdzie wielmożny wojewoda naznaczy, na dzień 19 miesiąca maja" ${ }^{\text {33 }}$. Do ziemian kijowskich zwrócił się wojewoda Stanisław Potocki, który wskazał im Włodzimierz jako miejsce obrad, z powodu niemożności ich odbywania w miejscu ,prawem obwarowanym”.

25 Instrukcja sejmiku trzech województw (kijowskiego, bracławskiego, czernihowskiego) posłom na sejm, we Włodzimierzu 20 III 1653, AJZR, cz. 2, t. I, s. 456-463 (cyt. fragment s. 457-458). Czytamy też, że sejmik odbył się w cerkwi katedralnej unickiej, s. 457.

26 J. Stolicki, Sejmiki ukrainne..., s. 229.

27 Deklaracye Woiewodztw Koronnych, VL, t. IV, s. 198-202.

28 Laudum sejmiku relacyjnego województwa bracławskiego, we Włodzimierzu 28 IV 1653 , CDIAUK, f. 28, ks. 89, k. 703-704.

29 Atestacja szlachty województwa bracławskiego deputatom do trybunału, we Włodzimierzu 15 IX 1653, CDIAUK, f. 28 , ks. 89, k. 939v-940v.

30 Oblata elekcji deputackiej województwa kijowskiego, we Włodzimierzu 15 IX 1653, CDIAUK, f. 28, ks. 89, k. 941-941v; Oblata elekcji deputackiej województwa czernihowskiego, we Włodzimierzu 15 IX 1653, CDIAUK, f. 28, ks. 89, k. 941v-942v.

31 Instrukcja sejmiku trzech województw (kijowskiego, bracławskiego, czernihowskiego) posłom na sejm, we Włodzimierzu, 31 XII 1653, AJZR, cz. 2, t. I, s. 464-474.

32 Uniwersał kasztelana kijowskiego Zbigniewa Gorajskiego do szlachty województwa kijowskiego, w Radzięcinie 14 XII 1653, CDIAUK, f. 28, ks. 89, k. 1059-1059v.

33 Uniwersał Jana Kazimierza do obywateli województwa bracławskiego, zwołujący sejmik przedsejmowy, w Warszawie 7 IV 1654, CDIAUK, f. 28, ks. 90, k. 786-786v; Uniwersał Jana Kazimierza do obywateli województwa czernihowskiego, zwołujący sejmik przedsejmowy, w Warszawie 7 IV 1654, CDIAUK, f. 28, ks. 90, k. 791-792v; Uniwersał wojewody kijowskiego Stanisława Potockiego do obywateli województwa kijowskiego, w sprawie odbycia sejmiku przedsejmowego, pod Barem 24 IV 1654, CDIAUK, f. 28, ks. 90, k. 792v-793. 
Sejmiki relacyjne zostały wyznaczone we Włodzimierzu na 7 sierpnia, a w przypadku zagrożenia tego miasta miały się odbyć w Lublinie, podobnie planowano przeprowadzenie elekcji deputackiej ${ }^{34}$.

W uchwałach sejmików wrześniowych jest napisane, że odbywają się we Włodzimierzu zgodnie z postanowieniami ostatnich konstytucji. Czernihowianie napisali: „zjachawszy się tu do Włodzimierza, kędy podczas żałosnego wygnania od dóbr i majętności naszych, zjazdy i sejmiki nasze za deklaracyją sejmową odprawujemy" ${ }^{35}$. Kwestię tę poruszono też w postanowieniu Bracławian ${ }^{36}$.

Sejmiki ukrainne przed sejmem w 1655 roku obradowały we Włodzimierzu, ale nie zostało to w obu instrukcjach podkreślone. Nowe miejsce było już dla szlachty oczywiste ${ }^{37}$.

W konstytucjach sejmu 1655 roku zapisano:

Woiewodztwo Kiiowskie we Włodzimierzu, pro die quinta Iulij, a in casu periculi od nieprzyjaciela w Lublinie, u Oycow Bernardynow. Woiewodztwo Bracławskie, we Włodzimierzu. Woiewodztwo Czerniechowskie, we Włodzimierzu relacyą odprawi na Seymiku Electionis deputata, insze zaś Seymiki Electionum na Urzędy Ziemskie ad feliciora tempora do Czerniechowa sobie odkładaią ${ }^{38}$.

Zastanawiać może fakt odłożenia elekcji na urzędy do momentu odzyskania Czernihowa. W połowie 1655 roku powrót do Czernihowa był bardziej odległy niż wcześniej. Sejmiki relacyjne odbyły się we Włodzimierzu ${ }^{39}$, podobnie jak znane późniejsze zgromadzenia z czasów potopu.

W deklaracjach podatkowych z sejmu w 1658 roku znajdujemy jedynie postanowienia dotyczące województwa czernihowskiego:

Seymik Relationis 18 Septemb. we Włodzimierzu mieć, y insze Seymiki, poki woyna trwać będzie, maią bydź tamże we Włodzimierzu odprawowane, gdzie y Urzędnicy Ziemscy, których ieszcze nie doszła elekcya, obrani bydź maią: na którą elekcyą Wielmożny Woiewoda Czerniechowski, uniwersał swoy podług prawa wydać powinien będzie ${ }^{40}$.

Zmieniono postanowienia, aby czekać z elekcjami urzędników do momentu powrotu do Czernihowa.

34 Deklaracye Woiewodztw y ziem Koronnych, VL, t. IV, s. 213-216.

35 Laudum sejmiku relacyjnego województwa czernihowskiego, we Włodzimierzu 15 IX 1654, AJZR, cz. 2, t. I, s. 475-478.

36 Elekcja deputacka województwa bracławskiego, we Włodzimierzu 14 IX 1654, CDIAUK, f. 28, ks. 90, k. 1056-1057; Elekcja deputacka województwa kijowskiego, we Włodzimierzu 14 IX 1654, CDIAUK, f. 28, ks. 90, k. 1057v-1058; Elekcja deputacka województwa czernihowskiego, we Włodzimierzu 14 IX 1654, CDIAUK, f. 28, ks. 90, k. 1057-1057v.

37 Instrukcja sejmiku województw bracławskiego i czernihowskiego posłom na sejm, 28 IV 1655, AJZR, cz. 2, t. II, Киев 1888, s. 4-7. Instrukcja sejmiku województwa kijowskiego posłom na sejm, 28 IV 1655, AJZR, cz. 2, t. II, , s. 7-13.

38 Deklaracye Seymikow Koronnych, VL, t. IV, s. 236.

39 Laudum sejmiku woj. kijowskiego, 5 VII 1655, CDIAUK, f. 28, ks. 91, k. 848-851; Laudum województwa kijowskiego na elekcji deputata uchwalone, 13 IX 1655, CDIAUK, f. 28, ks. 91, k. 951952; Elekcja deputatów województwa bracławskiego, CDIAUK, f. 28, ks. 91, k. 953-953v; Elekcja deputatów województwa czernihowskiego, CDIAUK, f. 28, ks. 91, k. 953v-954.

40 Deklaracye Woiewodztw, y ziem koronnych, VL, t. IV, s. 270. 
Przed sejmem w 1659 roku król zwołał sejmiki przedsejmowe województw ukrainnych: „W Włodzimirzu iuxta constitutionem anni 1655 naznaczamy”41. Tam zgromadziła się szlachta ukrainna. Sejm z tego roku uchwalił konstytucję „Seymiki y Elekcye Woiewodztw Ukrainnych". Była to właściwie pierwsza ustawa, w której wprost określono, że dopóki ziemianie tamtejsi nie powrócą do swych dóbr, mają odbywać swe zgromadzenia we Włodzimierzu. „Woiewodztwa, Kiiowskie, Bracławskie, Czerniechowskie, Seymiki swoie i elekcye wszelkie we Włodzimierzu podług deklaracyi pierwszych tychże Woiewodztw, poki ad possessiones dobr swoich nie przyidą odprawować maią, co im authoritate praesentis Conventus warujemy" 42 . Zgodnie z tą konstytucją wszystkie sejmiki interesujących nas województw w tym roku i następnym (zarówno relacyjne, jak i deputackie oraz elekcje) odbyły się we Włodzimierzu ${ }^{43}$. W większości uchwał uzasadniano to krótkim stwierdzeniem; jedynie w elekcji deputackiej Czernihowian z roku 1659 roku zapisano: „tu do Włodzimirza, kędy zwykliśmy akty publiczne województw naszych odprawować póki nie przyjdziemy do possesyj dóbr naszych i securitatem electionum i zjazdów" ${ }^{44}$.

Zwycięstwo cudnowskie dawało szlachcie ukrainnej duże nadzieje na powrót do swych posiadłości i zarazem do tradycyjnych miejsc odbywania zgromadzeń ziemskich. Przed sejmem w roku 1661 szlachta czernihowska zebrała się we Włodzimie$\mathrm{rzu}^{45}$, a obywatele kijowscy obradowali w innym miejscu, mianowicie w Żytomierzu. Jak uzasadniono $\mathrm{w}$ instrukcji danej posłom na sejm, stało się tak za ,universalem y innotescentią od jego królewskiey mosci" ${ }^{46}$. Instrukcja została oblatowana we Włodzimierzu, „ponieważ Żytomirski ad praesens vacat”. Warto zwrócić uwagę na dwie kwestie. Kijowianie po dziewięciu latach odbyli swój sejmik w zwyczajowym miejscu oraz oblatowali tekst swej instrukcji nie w Krzemieńcu czy Łucku, lecz we Włodzimierzu, w grodzie najbardziej oddalonym od Żytomierza. Może to świadczyć o utrzymujących się związkach ziemian kijowskich z grodem włodzimierskim. W Żytomierzu odbył się także sejmik elekcyjny podkomorzego kijowskiego. Jego postanowienia również zostały oblatowane $\mathrm{w}$ grodzie włodzimierskim ${ }^{47}$.

Na mocy konstytucji sejmu 1661 roku Czernihowianie mieli się zebrać na sejmiku relacyjnym we Włodzimierzu i tam też obradowali. Ciekawe postanowienia

${ }^{41}$ Uniwersały królewskie zwołujące sejmiki przedsejmowe województw bracławskiego, kijowskiego i czernihowskiego na dzień 28 lutego (wydane zostały w Toruniu 11 I 1659), CDIAUK, f. 28, ks. 96, k. 603-604, 611v-613v (cyt. fragment k. 603v).

42 VL, t. IV, s. 296. Zostało to potwierdzone w deklaracjach województw: Deklaracye podatkow Woiewodztw y Ziem, VL, t. IV, s. 307-310.

43 Uchwały tych zgromadzeń znajdują się w księgach grodzkich włodzimierskich 96 i 97.

44 Elekcja panów deputatów z województwa czernihowskiego, CDIAUK, f. 28, ks. 96, k. 947-947v.

45 Instrukcja sejmiku województwa czernihowskiego posłom na sejm, 28 III 1661, AJZR, cz. 2, t. II, s. 76-85. W instrukcji podkreślono powrót Ukrainy do posłuszeństwa po latach rebelii. Również dwa kolejne sejmiki elekcyjne, sędziego i podkomorzego czernihowskiego, zostały zwołane do Włodzimierza, CDIAUK, f. 28, ks. 98, k. 931v-932, 934v-935.

46 Instrukcja sejmiku województwa kijowskiego posłom na sejm, 28 III 1661, AJZR, cz. 2, t. II, s. $106-119$.

47 Oblata elekcji podkomorzego kijowskiego, w Żytomierzu 30 III 1661, CDIAUK, f. 28, ks. 98, k. $969 \mathrm{v}-970$. 
dotyczyły natomiast Kijowian: „A teraz Seymik Relationis we Włodzimierzu naznaczaią sobie rowno z Deputackim. A gdy do Żytomierza patebit aditus, tedy w kościele odprawować będą powinni, odtąd a nie w zamku naszym Seymiki, elekcye"48. Nie mamy informacji dotyczących sejmiku relacyjnego, elekcja deputatów do trybunału odbyła się natomiast we Włodzimierzu. Nie udało się więc ziemianom kijowskim na stałe powrócić do zwyczajowego miejsca odbywania swych zgromadzeń.

Istotne zmiany dotyczyły także szlachty bracławskiej. Sejmik przedsejmowy obradował, po raz pierwszy od wybuchu powstania, w starym miejscu, czyli w Winnicy. Dnia 10 stycznia 1661 roku Jan Kazimierz zwołał sejm i sejmiki. Dwa miesiące później wydał kolejny uniwersał, na mocy którego najbliższy sejmik przeniesiono do Winnicy. W dokumencie znajdujemy następujące wyjaśnienie owej decyzji:

Dogadzając doniesionej nam imieniem obywatelów województwa tegoż bracławskiego prośbie, ile gdy rzecz słuszną upatrujemy, aby immutatus w przeszłym zamieszaniu Ojczyzny sejmikowania województwa tego niebezpieczeństwa podległego ordo mógł być przywrócony. Ponieważ za sprawą i zrządzeniem Boskim pristinam nanciscitur tranquillitatem, żeby sejmiki [sic] przedsejmowy ten osobliwie suo loco odprawować się może tedy na miejsce zwyczajne z Włodzimirza przenoszamy go do Winnice, gdzie jako obywatele województwa tego bracławskiego na obradę publiczną, tak i poseł nasz z instancyją zjechać na czas w sejmikowych uniwersałach naznaczony mają ${ }^{49}$.

Nie mamy informacji o poselstwie Bracławian do króla, o którym wspomniano w uniwersale i podczas którego poruszono kwestię miejsca obrad. Nie dysponujemy również uchwałami sejmiku, ponieważ nie zostały one wpisane do ksiąg grodzkich włodzimierskich, a winnickie się nie zachowały.

W deklaracjach województw zapisano:

Seymik Relationis w Winnicy, die 16 Septembris ieżeli aditus patebit; a ieżeli non patebit, tedy we Włodzimierzu, iako y inne Seymiki wszystkie według dawnieyszych konstytucyi w kościele Oycow Dominikanow tamecznych. W czym od Wielmożnego Oboźnego Koronnego Starosty Winnickiego tempestive denunciatio do Grodów wszystkich Wołyńskich dwiema niedzielami podana, ma praecedere Seymik i Elekcye, gdy ad propria przyidą, w Winnicy maią bydź na potym odprawowane w kościele Oycow Iezuitow tamtecznych. Ponieważ farny funditus przez nieprzyiaciela zniesiony, w którym przedtym Seymiki wszelakie odprawowały się. Y Seymik przed Seymem, w tymże kościele Oycow Iezuitow w Winnicy odprawiony, approbuiemy ${ }^{50}$.

Kolejne zgromadzenia wszystkich województw odbyły się we Włodzimierzu. Szlachta czernihowska obradowała 20 sierpnia i 12 września $^{51}$. Sejmik deputacki

48 Deklaracye Woiewodztw y Ziem, VL, t. IV, s. 363; Elekcja deputatów województwa kijowskiego 12 IX 1661, CDIAUK, f. 28, ks. 98, k. 1268v-1269v: „,do Włodzimierza, kędy publiczne akcyje województwa naszego według konstytucyjej, dokąd do posesyjej dóbr naszych nie przydziemy województwu naszemu assignatum".

49 Uniwersał Jana Kazimierza do obywatelów województwa bracławskiego, w Krakowie 10 I 1661 , CDIAUK, f. 28, ks. 98, k. 866-868 (został on oblatowany przez Jerzego Szomakowicza, sługę kasztelana bracławskiego). Uniwersał Jana Kazimierza do obywatelów województwa bracławskiego, w Warszawie, 12 III 1661, CDIAUK, f. 28, ks. 98, k. 912-913.

50 Deklaracye Woiewodztw y Ziem, VL, t. IV, s. 368.

51 Laudum sejmiku relacyjnego województwa czernihowskiego, 20 VIII 1661, CDIAUK, f. 28, ks. 98, k. 1212v-1214; Elekcja deputatów województwa czernihowskiego, 12 IX 1661, CDIAUK, 
województwa kijowskiego również odbył się w tym mieście, zgodnie z konstytucją. Ważne dokumenty dotyczą obywateli bracławskich. Oboźny koronny Andrzej Potocki wydał uniwersał, w którym wyznaczył Włodzimierz jako miejsce obrad, co uzasadnił stacjonowaniem licznych oddziałów ordy w okolicach Winnicy ${ }^{52}$. Skutkiem tego kolejne zgromadzenia (deputackie oraz elekcje podsędka i pisarza) odbyły się właśnie we Włodzimierzu, co podkreślono w elekcji deputatów.

Według uniwersałów zwołujących kolejny sejm, w 1662 roku, zgromadzenia szlachty kijowskiej oraz czernihowskiej miały się odbyć we Włodzimierzu, a bracławskiej „na miejscu zwykłem” w Winnicy ${ }^{53}$. Sejmik województwa bracławskiego odbył się jednak także we Włodzimierzu. W instrukcji dla posłów znajdujemy wyjaśnienie, że przyczyną zmiany miejsca były niepokoje wojenne ${ }^{54}$. Interwencję w kwestiach związanych $\mathrm{z}$ bezpieczeństwem $\mathrm{w}$ okolicach Winnicy posłowie bracławscy mieli zgłosić w suplice do króla.

Konstytucja sejmu 1662 roku wyznaczyła zgromadzenia relacyjne trzech województw ukrainnych we Włodzimierzu ${ }^{55}$, ale szlachta bracławska oraz kijowska podejmowała próby debatowania $\mathrm{w}$ innych miejscach. 7 czerwca 1662 roku monarcha zwołał sejmik województwa bracławskiego na dzień 26 tegoż miesiąca „w Winnicy albo we Włodzimirzu”. Ziemianie zebrali się we Włodzimierzu, „ponieważ jeszcze do naszego własnego województwa per hostilitatem non patet aditus" ${ }^{\prime 6}$. Kolejna próba obradowania w Winnicy była podjęta w następnym roku. Król zwołał sejmiki w ziemiach na dzień po elekcji deputackiej. W uniwersale do województwa bracławskiego wyznaczył Winnicę na miejsce obrad ${ }^{57}$. Informował, że podjęto wyprawę wojskową, aby obywatele ukrainni powrócili do swych posiadłości. Są to zapowiedzi planowanej wyprawy zadnieprzańskiej. W uniwersale do województwa kijowskiego król nie podał miejsca odbycia sejmiku ${ }^{58}$. Kijowianie zjechali się do Włodzimierza.

Bracławianie też odbyli obydwa zgromadzenia we Włodzimierzu. Uzasadniono to w uchwale sejmiku podeputackiego:

f. 28 , ks. 98 , k. 1267v-1268. Tu czytamy: „do Włodzimirza przez konstytucyją województwu naszemu czernihowskiemu do odprawowania wszytkich sejmików naszych, miejsce to mając naznaczone".

52 Uniwersał Andrzeja Potockiego do obywatelów województwa bracławskiego, w Nowosielicach 30 VIII 1661, CDIAUK, f. 28, ks. 98, k. 1227-1227v. Postanowienia tych sejmików - k. 1269v-1270v, $1286-1287 \mathrm{v}, 1289 \mathrm{v}-1291$.

53 Uniwersał Jana Kazimierza na sejmik przedsejmowy województwa bracławskiego w Winnicy, 30 I 1662, w Bielsku 7 I 1662, CDIAUK, f. 28, ks. 100, k. 1016-1016v.

54 Instrukcja sejmiku województwa bracławskiego posłom na sejm, styczeń 1662, AJZR, cz. 2, t. II, s. $120-125$.

55 Deklaracye Seymikow Relationum, VL, t. IV, s. 412.

56 Uniwersał Jana Kazimierza do szlachty województwa bracławskiego, 7 VI 1662, CDIAUK, f. 28, ks. 100, k. 1394v-1395v; Laudum sejmiku relacyjnego województwa bracławskiego, 3 VII 1662, CDIAUK, f. 28, ks. 100, k. 1428-1430v.

57 Uniwersał Jana Kazimierza do szlachty województwa bracławskiego, we Lwowie 8 VIII 1663, CDIAUK, f. 28, ks. 101, k. 1174-1175v. Uchwały sejmików z 10 i 11 IX - k. 1211-1212, 1222-1225v.

58 Uniwersał Jana Kazimierza do szlachty województwa kijowskiego, we Lwowie 8 VIII 1663, CDIAUK, f. 28, ks. 101, k. 1214v-1216. Jest zapisane: „na miejscu zwyczajnym”. W laudum sejmiku podeputackiego też nie znajdujemy dodatkowych informacji, CDIAUK, f. 28, ks. 101, k. 1213-1214. 
I aczkolwiek województwo nasze zawsze sobie życzyło, abyśmy sejmiki i wszelakie conventicula nasze w Winnicy jako in proprio solo województwa naszego odprawowali. I lubo nam JKM uniwersałem z kancelaryjej swojej wydanym sejmik w Winnicy ad diem wysz mianowany, złożyć i naznaczyć raczył... Ponieważ neque aditus securus do Winice patet neque ulla securitas do mieszkania w domach naszych manet, ponieważ wojska JKMci w Ukrainie i do województwa naszego nie weszły ${ }^{59}$.

Do końca 1664 roku szlachta ukrainna obradowała we Włodzimierzu. 17 grudnia odbył się sejmik elekcyjny sędziego kijowskiego ${ }^{60}$. Przeciwko niemu część szlachty, zgromadzona na sejmiku przedsejmowym, zgłosiła protestację i przedstawiła trzy argumenty świadczące o nieważności elekcji. Jeden z nich dotyczył miejsca obrad sejmiku. Elekcja odbyła się ,nie na zwyczajnym miejscu, to jest nie w województwie kijowskim, w Żytomirzu (gdzieby wszyscy ichm. panowie obywatele tameczni zjechali się)" "61. Protestacja była konsekwencją sporów wśród Kijowian, zaś argument o miejscu obrad był jedynie pretekstem. Należy tu jednak zauważyć, że kilkakrotnie obywatele województwa w pierwszym półroczu 1665 roku zjeżdżali się do Żytomierza, zresztą zgodnie z uniwersałami ${ }^{62}$. Nie wiadomo, gdzie odbył się sejmik relacyjny, lecz deputacki obradował ponownie we Włodzimierzu ${ }^{63}$, podobnie jak wszystkie znane zgromadzenia w następnym roku. Możemy więc ocenić, że odbywanie przez szlachtę kijowską swych zjazdów w Żytomierzu było tymczasowe i ograniczyło się do pierwszej połowy 1665 roku.

Kolejne interesujące nas informacje pochodzą z roku 1666 i dotyczą sejmiku bracławskiego. W uchwale sejmiku elekcyjnego podkomorzego bracławskiego z 2 marca czytamy: „nie derogując nic sejmikowi poselskiemu winnickiemu, który legitime po wjeździe jm. pana starosty winnickiego odprawił się"64. Nie można ustalić, o jakim sejmiku przedsejmowym wspomina się w tym dokumencie. Poprzednie zgromadzenia przedsejmowe Bracławian odbywały się we Włodzimierzu. Nie wiadomo też nic o wspomnianych wydarzeniach.

W laudum uchwalonym podczas elekcji deputata znajdujemy informacje, że sejmik przedsejmowy został wyznaczony w Winnicy: „Dowiedziawszy się, iż listy sejmikowe do Winnice powiezione, a tam żadna securitas odprawienia sejmiku być nie

59 Ibidem, k. 1222.

60 Elekcja sędziego województwa kijowskiego, 17 XII 1664, CDIAUK, f. 11, ks. 15, k. 160-161v.

${ }^{61}$ Oblata ekstraktu protestacyjej od ichm. panów obywatelów województwa kijowskiego o nieważności elekcyjej sędziego we Włodzimirzu ekspedyjowanej, CDIAUK, f. 11, ks. 15, k. $107-110$. Protestację oblatował 20 II podczaszy kijowski Jan Proskura Suszczański.

62 Oblata elekcyjej podsędka województwa kijowskiego, 13 II 1665, CDIAUK, f. 11, ks. 15, k. 99v100 (stosując się do innotescencyjej S. Czarnieckiego z 6 II). Instrukcyja ichm. posłom województwa kijowskiego na sejm od ichm. panów obywatelów dana, 19 II 1665 (oblata 20 II 1665 w Zytomierzu), CDIAUK, f. 11, ks. 15, k. 103v-107.

63 Elekcja deputacka województwa kijowskiego, 14 IX 1665, CDIAUK, f. 28, ks. 103, k. $1501 \mathrm{v}-1502 \mathrm{v}$.

${ }^{64}$ Elekcja podkomorzego bracławskiego, we Włodzimierzu 2 III 1666, CDIAUK, f. 28, ks. 105, k. $854-854 \mathrm{v}$. 
może, propter motum hostilitatis, jako świże wiadomości zachodzą i gród wakuje"65. W związku z tym postanowiono, aby przypadający wkrótce sejmik przedsejmowy odbył się we Włodzimierzu. Nie możemy więc ostatecznie rozstrzygnąć, czy w ogóle, a jeżeli tak, to ile razy tamtejsi obywatele zebrali się w swym zwyczajowym miejscu. Można jedynie wyciągnąć wniosek, że sporadycznie próbowali obradować w Winnicy.

Zasadnicze zmiany w sytuacji nastąpily pod koniec 1666 roku. Wtedy ostatnie chorągwie koronne stacjonujące na Bracławszczyźnie zostały rozbite przez wojska kozacko-tatarskie. Nie było już możliwości odbywania tam sejmików.

Pod koniec grudnia 1666 roku król zwołał kolejny sejm oraz sejmiki do Włodzimierza ${ }^{66}$. Potem do szlachty bracławskiej zwrócił się wojewoda bracławski Jan Potocki, który potwierdził, że sejmik bracławski ma obradować we Włodzimierzu. Sejmiki przedsejmowe ukrainne odbyły się w tym mieście.

W styczniu 1667 roku, w wyniku zawarcia traktatu andruszowskiego, w państwie carów znalazło się całe dawne województwo czernihowskie i część kijowskiego. Podczas obrad sejmu wiadomo już było o zawarciu rozejmu w Andruszowie, ale nie wpłynęło to na postanowienia konstytucji w kwestii miejsca odbywania sejmików. Potwierdzono dotychczasowe prawa. Konstytucja „Sądy Woiewództwa Kiiowskiego" dotyczyła tylko spraw sądowych ${ }^{67}$. Sejmiki relacyjne ukrainne miały się odbyć we Włodzimierzu i tam też się odbyły. Nie zajmowano się wówczas miejscem obrad, co świadczy o tym, że traktowano je jako oczywiste ${ }^{68}$.

Po zwycięstwie cudnowskim realne wydawało się odzyskanie Ukrainy. Szybko okazało się jednak, że niemożliwe jest zajęcie jej lewobrzeżnej części, gdzie Moskwa

${ }_{65}$ Laudum sejmiku deputackiego województwa bracławskiego, we Włodzimierzu 13 IX 1666, CDIAUK, f. 28, ks. 105, k. 1237v-1238. W księdze są uniwersały z 31 VIII do województwa kijowskiego i czernihowskiego wyznaczające sejmiki na 28 IX, brak natomiast takiego do szlachty bracławskiej.

${ }_{66}$ Uniwersał Jana Kazimierza do szlachty województwa kijowskiego, w Warszawie 31 XII 1666, CDIAUK, f. 28, ks. 107, k. 10-12v. Analogiczne uniwersały do województwa czernihowskiego, CDIAUK, f. 28 , ks. 107 , k. 15-17v, i bracławskiego, k. $17 \mathrm{v}-19 \mathrm{v}$. Uniwersał wojewody bracławskiego Jana Potockiego do szlachty województwa, we Lwowie 25 I 1667, CDIAUK, f. 28, ks. 107, k. 26-26v. Instrukcja województwa kijowskiego posłom na sejm, 7 II 1667, AJZR, cz. 2, t. II, s. 225-230. Instrukcja województwa czernihowskiego posłom na sejm, 7 II 1667, CDIAUK, f. 28, ks. 107, s. 221-225.

${ }_{67}$ VL, t. IV, s. 439. Deklaracye Woiewodztw y Ziem Koronnych, VL, t. IV, s. 456. „Seymik w Żytomierzu Wielmożny Woiewoda Kiiowski przez uniwersał swoy upatrzywszy czas spokojny, złoży”, czyli w przyszłości. „Woiewodztwo Bracławskie... Tamże we Włodzimierzu wszystkie Seymiki, elekcye składać, y wszelkie solennitates odprawować maią, w kościele Oycow Dominikanów, dotąd poki in reali et pacifica possessione dobr swoich zostawać nie będą. Woiewodztwo Czerniechowskie... we Włodzimierzu, kędy wszystkie Seymiki i elekcye tak Deputackie, iako y na urzędy wszelakie durante armistitio y poki nie przyidzie do possessyi dobr swoich według przeszłych konstytucyi mieć będzie". VL, t. IV, s. 460.

${ }_{68}$ Sejmik relacyjny województwa czernihowskiego, AJZR, cz. 2, t. II, s. 230-233; Sejmik relacyjny województwa bracławskiego, 22 VI 1667, CDIAUK, f. 28, ks. 107, k. 400-401v. Laudum województwa kijowskiego, 7 VI 1667, CDIAUK, f. 28, ks. 107, k. 328-328v; znamy też dwie elekcje: Elekcja pisarza ziemskiego kijowskiego, we Włodzimierzu, 31 III 1667, CDIAUK, f. 28, ks. 107, k. 188-188v; Elekcja podkomorzego kijowskiego, we Włodzimierzu, 2 IV 1667, CDIAUK, f. 28, ks. 107, k. 198-198v. Włodzimierz został wyznaczony jako miejsce sejmików w uniwersałach wojewody kijowskiego Michała Jana Stanisławskiego, CDIAUK, f. 28, ks. 107, k. 137-138, 138v-139v. 
utrzymała swój stan posiadania. Obywatele czernihowscy nie mieli więc szans na powrót do swych domostw, z których uciekli w czerwcu 1648 roku. Ukraina prawobrzeżna znalazła się w polskiej strefie wpływów, ale stawały się one coraz słabsze, zwłaszcza po niepowodzeniu wyprawy zadnieprzańskiej. Ponadto były to tereny bardzo niespokojne ze względu na powstania kozackie i przechody ordy. Spowodowało to, że nie był możliwy powrót sejmików województw kijowskiego, a zwłaszcza bracławskiego do swych zwyczajowych siedzib, mimo podejmowanych prób.

W kolejnych latach wszystkie sejmiki ukrainne odbywały się we Włodzimierzu i tak już pozostało do końca panowania Jana III Sobieskiego. W przypadku sejmiku czernihowskiego było to naturalne. Rozejm andruszowski kilkakrotnie przedłużano, a w 1686 roku obydwa państwa podpisały wieczysty pokój i ziemie województwa przypadły Moskwie.

Na Bracławszczyźnie do 1672 roku toczyły się walki między oddziałami koronnymi a Kozakami. Na mocy układu zawartego w Buczaczu Ukraina prawobrzeżna stała się lennem Porty. Panowanie osmańskie zakończyło się w roku 1683, ale trudno było mówić tam o spokoju. Bracławianie zaczęli postulować przeniesienie swych sejmików do Winnicy już po śmierci Jana III $^{69}$. Odkładano jednak tę decyzję z powodu niemożności zapewnienia spokoju. Kilkakrotnie, dość naiwnie, domagano się od starosty winnickiego przywrócenia tam bezpieczeństwa.

Województwo kijowskie obejmowało natomiast ziemie pozostające w Rzeczypospolitej, ale mieszkali w nim też Kozacy, co przyczyniało się do konfliktów między nimi a szlachtą. Mimo odbywania sejmików we Włodzimierzu obywatele dokładali starań, aby prowadzono księgi w grodach województwa kijowskiego. W księgach grodzkich owruckich i kijowskich oblatowano coraz więcej dokumentów związanych z życiem publicznym. Przynoszono je jako ekstrakty z grodu włodzimierskiego. Nie zachowały się, ale były prowadzone księgi żytomierskie ${ }^{70}$. Prowadzenie tych ksiąg stanowiło jeden z czynników skłaniających część szlachty do wyrażania deklaracji powrotu zgromadzeń do Żytomierza (ale nie do podejmowania konkretnych działań). Sformułowano je na przykład w instrukcji z 1678 roku: „Sejmiki województwa kijowskiego, aby per authoritatem legis na zwyczajne do Żytomirza były przeniesione miejsce, in casu hostilitatis do Owrucza, jako w spokojniejszym kraju, aby tam były odprawowane ichm. panowie posłowie o to starać się mająa" ${ }^{\prime \prime}$. Przełomem nie była też konstytucja z sejmu w 1683 roku. W niej potwierdzono powrót szlachty z ziem prawobrzeżnych województwa kijowskiego do swych dóbr. Zajęto się też sprawami jej dotyczącymi, zwłaszcza sądami. Stany zadecydowały jednak, aby sejmiki w dalszym ciągu odbywały się we Włodzimierzu ${ }^{72}$. Po 1683 roku pojawiały się też

${ }^{69}$ Laudum sejmiku przedkonwokacyjnego województwa bracławskiego, 27 VII 1696, CDIAUK, f. 28 , ks. 141 , k. $852 \mathrm{v}-854 \mathrm{v}$; Instrukcja sejmiku województwa bracławskiego posłom na sejm, 26 III 1698, AJZR, cz. 2, t. III, Киев 1911, s. 22-32.

${ }^{70} \mathrm{~W}$ trzech księgach żytomierskich znajdujemy oblaty z czasów panowania Jana Kazimierza. Kolejne zaś pochodzą z okresu panowania Augusta II.

71 Instrukcja sejmiku województwa kijowskiego posłom na sejm, 3 XI 1678, CDIAUK, f. 28, ks. 121, k. 1587.

72 Integritas Woiewodztwa Kiiowskiego, VL, t. V, s. 327. 
propozycje, aby sejmiki ukrainne przenieść do Łucka, Ołyki czy Korca. Były jednak i takie, aby pozostać we Włodzimierzu.

Postulaty przeniesienia obrad do Żytomierza częściej znajdujemy już po śmierci Jana III. Można wymienić tu protestacje dotyczące zgromadzeń z 29 grudnia 1696 roku oraz z maja 1698 roku $^{73}$. Przedstawiali je ziemianie kijowscy, którzy mieszkali $\mathrm{z}$ dala od Włodzimierza. Argumentowali, że zbierający się w grodzie włodzimierskim nie reprezentują obywateli województwa, którzy dość często nie mogą przybywać na sejmiki właśnie z powodu znacznej odległości tego miasta od ich posiadłości. Sprawa miejsca sejmiku bywała wykorzystywana także do rywalizacji wewnętrznej między grupami. Jedna dążyła do odbywania zgromadzeń w Żytomierzu, druga we Włodzimierzu.

Sejmik czernihowski obradował we Włodzimierzu także w czasach saskich. Zgromadzenia województw kijowskiego i bracławskiego powróciły zaś w XVIII wieku do Żytomierza i Winnicy, ale przedstawienie tych okoliczności zasługuje na osobne rozpatrzenie.

W drugiej połowie XVII wieku na wygnaniu funkcjonował też sejmik województwa podolskiego. Był on już przedmiotem badań autora niniejszego tekstu. Podolanie odbywali swe zjazdy najpierw w Haliczu (pierwszy odbył się tam 20 listopada, a następny 13 grudnia $1672 \mathrm{r}^{74}$ ). Nie znamy ich uchwał, zachowały się jedynie zapisy w protokołach. Potem Halicz jako miejsce zgromadzeń egzulantów wyznaczyła konstytucja sejmu pacyfikacyjnego z 1673 roku $^{75}$. Od roku 1677 miejscem zjazdów Podolan był Lwów ${ }^{76}$. W 1699 roku, czekając na zwrot Kamieńca, kilkakrotnie debatowali w Okopach Świętej Trójcy ${ }^{77}$. Pierwszy sejmik po powrocie odbył się tam w katedrze 25 września 1699 roku $^{78}$.

Warto jeszcze zwrócić uwagę na konkretne miejsca obrad. W latach 1648-1649 odbywały się tam, gdzie było bezpiecznie, znamy przynajmniej jeden przykład zgromadzenia poza murami miasta. W 1649 roku wyznaczono jako jednorazowe miejsca kościoły Dominikanów w Lublinie (zwyczajowe miejsce sejmiku lubelskiego) i Łucku oraz Franciszkanów we Lwowie (też zwyczajowe). Potem istniała także możliwość odbycia zgromadzeń w Lublinie u Bernardynów, ale nie doszło do tego. W 1649 roku król zwołał ziemian ukrainnych do cerkwi katedralnej unickiej we Włodzimierzu i w niej zaczęli się oni gromadzić. Mocno akcentowano w różnych uchwałach, że

73 Manifestacja obywatelów województwa kijowskiego przeciwko laudum sejmiku pokonwokacyjnego, odbytego 29 XII 1696, CDIAUK, f. 15, ks. 10, k. 147-148; Protestacja obywatelów województwa kijowskiego przeciwko pewnym punktom sejmiku, CDIAUK, f. 15, ks. 10, k. 433-434v. Autorem obu protestacji był Remigian Suryn.

74 Akta sejmiku podolskiego in hostico 1672-1698, wyd. i oprac. J. Stolicki, Kraków 2002, nr I, II [dalej: ASP].

75 Ukontentowanie exulum Woiew. Podolskiego, VL, t. V, s. 75.

76 Sejmiki województwa podolskiego i sady, VL, t. V, s. 229-230; ASP, nr XI.

77 Pisałem o tym wcześniej: Powrót Podola do Polski [w:] Balcanica Posnaniensia. Acta et studia, t. XIII: Traktaty karlowickie z 1699 roku i ich następstwa, red. I. Czamańska, W. Szulc, Poznań 2003, s. $135-147$.

78 Uchwała była dwukrotnie publikowana; Laudum sejmiku województwa podolskiego, w Kamieńcu 25 IX 1699, AJZR, cz. 2, t. III, s. 85-88; J. Stolicki, Powrót..., aneks III. 
tam odbywają się sejmiki deputackie województwa wołyńskiego (raz na trzy lata), aby podkreślić, że jest to miejsce zwyczajowe. W 1653 roku elekcje deputatów województw kijowskiego i czernihowskiego odbyły się we Włodzimierzu, ale w kościele Dominikanów. Stanowiło to prawdopodobnie konsekwencję faktu, że wówczas Wołynianie odbyli swoją w cerkwi katedralnej. Byłoby uciążliwe i niepraktyczne, gdyby aż cztery województwa zebrały się w jednym kościele, a pamiętajmy, że sejmik deputacki należało zakończyć w tym samym dniu. W 1661 roku w deklaracjach wyznaczono klasztor Dominikanów jako miejsce przyszłych sejmików bracławskich we Włodzimierzu, co zostało potwierdzone w deklaracjach z 1667 roku $^{79}$. Od 1661 roku szlachta bracławska zbierała się właśnie u Dominikanów. Było to też miejsce zgromadzeń kijowskich. Wspomniana konstytucja z 1661 roku wyznaczyła kościół Dominikanów jako miejsce sejmiku relacyjnego czernihowskiego ${ }^{80}$. Nie możemy potwierdzić, w której świątyni debatowali Czernihowianie w tym roku, ale wiadomo, że w kolejnych latach gromadzili się w cerkwi unickiej. Często jednak w dokumentach nie jest wymieniony konkretny kościól, stąd nie wiadomo, gdzie dokładnie zebrali się obywatele w określonych latach (np. 1661-1664).

Klasztor Ojców Dominikanów we Włodzimierzu został założony pod koniec XV wieku i istniał do 1850 roku, kiedy nie odnowiono go po kolejnym pożarze. Klasztor zbudowano w 1497 roku, składał się on z kościoła i dwóch krótkich skrzydeł. W 1750 roku został zniszczony przez pożar, a następnie przebudowany ${ }^{81}$. Cerkiew unicka była wcześniej katedrą prawosławną (Sobór Uspieński). Po przyłączeniu się do unii biskupa Hipacego Pocieja przeszła w użytkowanie unitów. W tym czasie kilkakrotnie ją przebudowano. Po likwidacji diecezji unickiej przekształcono świątynię w magazyn, a pod koniec XIX wieku przebudowano ją, aby przywrócić jej wygląd cerkwi ruskiej.

Sejmiki w Żytomierzu początkowo odbywały się w zamku. W 1661 roku zostały przeniesione do kościoła, ale nie wiemy, w którym miejscu odbyło się tych kilka zgromadzeń z 1665 roku. Na mocy wspomnianej konstytucji z 1661 roku, gdyby sejmiki powróciły do Winnicy, przeniesiono ich miejsce z kościoła farnego do klasztoru Jezuitów.

Sejmik województwa podolskiego zbierał się w Haliczu w klasztorze Franciszkanów (nie było to zwyczajowe miejsce dla tej ziemi), a potem we Lwowie także u Franciszkanów (gromadziła się tam szlachta ziemi lwowskiej, ale te zjazdy nie odbywały się często). Kościół Ojców Franciszkanów we Lwowie pod wezwaniem Świętego Krzyża znajdował się w zachodniej części miasta, tuż przy murach. W czasach, gdy zbierali się tam Podolanie, budowla była już po odbudowie dokonanej pod koniec XVI wieku (po wcześniejszym pożarze). Kościół miał trzy nawy i kilka kaplic. Został zamknięty przez Austriaków - podobnie jak klasztor - w 1784 roku. W 1848 roku zniszczono go, a ruiny rozebrano ${ }^{82}$.

79 Zob. przyp. 50, 67. VL, t. IV, s. 368, 460.

80 VL, t. IV, s. 368.

81 M. Kuczinko, Rzymskokatolickie budowle sakralne końca XV-XVIII w. we Włodzimierzu Wotyńskim [w:] Do piękna nadprzyrodzonego, red. K. Mart, Chełm 2003, s. 80-97.

82 Енциклопедія історії Львова, т. ІІІ, ред. А. Козицький, Львів 2010, стр. 449. 
Sejmiki staropolskie odbywały się w miejscach zgodnych z prawem i zwyczajem, co zwykle podkreślano w uchwałach. Odstępstwa od tej reguły były jeszcze mocniej uzasadniane. Klęski wojenne spowodowały konieczność obradowania in hostico. Egzulanci starali się więc o znalezienie nowych miejsc na wygnaniu, w miarę dla nich wygodnych, w których odbywały się już miejscowe zgromadzenia. Ponadto konieczność odbycia sejmiku w innym miejscu wyjaśniano we wszelkich związanych $\mathrm{z}$ nim dokumentach. Najlepiej, aby było ono wyznaczone w uniwersale i uzasadnione w laudum, a także potwierdzone przez konstytucję. Podkreślano też faktyczny brak możliwości zgromadzenia się obywateli w miejscu zwyczajowym, co świadczyło o przywiązaniu szlachty do prawa dotyczącego sejmików.

\section{BIBLIOGRAFIA}

\section{Źródła rękopiśmienne}

Archiwum Państwowe w Lublinie: Księgi grodzkie lubelskie, Relacje Manifestacje Oblaty (RMO), ks. 77.

Biblioteka PAU i PAN w Krakowie: Teki Pawińskiego 8355.

Centralnyj Dierżawnyj Istorycznyj Archiw Ukrainy u Kijewi (Центральний державний історичний архів України у Києві):

f. 11 (księgi grodzkie żytomierskie), ks. 13, 14, 15,

f. 15 (księgi grodzkie owruckie), ks. 10,

f. 28 (księgi grodzkie włodzimierskie), ks. 85, 89-91, 96-98, 100, 101, 103, 105, 107, 121, 141.

\section{Źródła drukowane}

Akta grodzkie i ziemskie z czasów Rzeczypospolitej Polskiej z archiwum tzw. bernardyńskiego we Lwowie, t. XXI: Lauda sejmikowe, (t. II: Lauda wiszeńskie 1648-1673), oprac. A. Prochaska, Lwów 1911.

Akta sejmiku podolskiego in hostico 1672-1698, wyd. i oprac. J. Stolicki, Kraków 2002.

Latopisiec albo kroniczka Joachima Jerlicza, z rękopisu wydał K.W. Wóycicki, Warszawa 1853.

Ojczyste spominki w pismach do dziejów dawnej Polski..., t. II, z rękopisów zebrał A. Grabowski, Kraków 1845.

Volumina Legum, t. III, IV, V, Warszawa 1980.

Архив Юго-западной России, издаваемый временной комиссией для разбора древних актов, состоящей при Киевском, Подольском и Вольнском генерал-губернаторе, Ч. 2: Т. І, Киев 1861, Ч. 2: Т. ІІ, Киев 1888, Ч. 2: Т. ІІІ, Киев 1910 (Archiw jugo-zapadnoj Rosii..., cz. 2, t. I-III). 


\section{Opracowania}

Kuczinko M., Rzymskokatolickie budowle sakralne końca XV-XVIII w. we Włodzimierzu Wotyńskim [w:] Do piękna nadprzyrodzonego, red. K. Mart, Chełm 2003, s. 80-97.

Mazur K., W stronę integracji z Korona. Sejmiki Wolynia i Ukrainy w latach 1569-1648, Warszawa 2006.

Ochmann S., Sejm koronacyjny Jana Kazimierza w 1649 r., Wrocław 1988.

Stolicki J., Powrót Podola do Polski [w:] Balcanica Posnaniensia. Acta et studia, t. XIII: Traktaty karłowickie z 1699 roku i ich następstwa, red. I. Czamańska, W. Szulc, Poznań 2003.

Stolicki J., Prolongowanie sejmów $w$ drugiej połowie XVII wieku, „Czasopismo Prawno-Historyczne" 1997, t. XLIX, z. 1-2.

Stolicki J., Sejmiki ukrainne w latach 1648-1702. Problemy badawcze [w:] PATRIMO-

NIUM Студї з ранньомодерної історії Центрально-Східної Європи, Том 1:

Ранньомодерна людина: простір - влада - право XVI-XVIII cm., Київ-Краків 2015. Енциклопедія історії Львова, т. III, ред. А. Козицький, Львів 2010. 